\title{
Influence of chronic kidney disease on anticoagulation levels and bleeding after primary percutaneous coronary intervention in patients treated with unfractionated heparin
}

\author{
Wouter J. Kikkert ${ }^{1} \cdot$ Peter M. van Brussel $^{1} \cdot$ Peter Damman $^{1} \cdot$ Bimmer E. Claessen $^{1}$ • \\ Jan P. van Straalen ${ }^{2} \cdot$ Marije M. Vis ${ }^{1} \cdot J_{a n}$ Baan Jr. ${ }^{1} \cdot K$ arel T. Koch $^{1}$ \\ Ron J. Peters ${ }^{1} \cdot$ Robbert J. de Winter $^{1} \cdot$ Jan J. Piek $^{1} \cdot$ Jan G. P. Tijssen $^{1}$ • \\ Jose P. S. Henriques
}

Published online: 4 August 2015

(C) The Author(s) 2015. This article is published with open access at Springerlink.com

\begin{abstract}
Unfractionated heparin (UFH) plasma protein binding and elimination might be impaired in patients with chronic kidney disease (CKD—defined as creatinine clearance $<60 \mathrm{ml} / \mathrm{min}$ ). It is currently unknown at which UFH bolus dose persistent prolongation of activated partial thromboplastin time (aPTT) occurs in ST-segment elevation myocardial infarction (STEMI) patients with CKD. We investigated the effect of different UFH bolus doses on the first aPTT measured within 6 and $12 \mathrm{~h}$ after PPCI in 1071 STEMI patients with and without CKD undergoing primary percutaneous coronary intervention (PPCI) between 1-1-2003 and 31-07-2008. In the first $6 \mathrm{~h}$ after PPCI, aPTT ratio was 5.1 for patients with CKD versus 3.4 for those without $(\mathrm{p}<0.001)$. The proportion of patients with markedly high aPTTs (aPTT ratio $\geq 4$ times control) increased with increasing heparin bolus and beyond $130 \mathrm{IU} / \mathrm{kg}$ there was a marked difference between patients with and without CKD (74.1 and $42.3 \%$ respectively, $\mathrm{p}<0.001)$. By multivariable analysis, CKD was associated with an increased risk of markedly high aPTTs (odds ratio (OR) 2.04; $95 \%$ confidence interval (CI) 1.27-3.27), driven largely by an increased risk of aPTT prolongation in
\end{abstract}

Electronic supplementary material The online version of this article (doi:10.1007/s11239-015-1255-x) contains supplementary material, which is available to authorized users.

Wouter J. Kikkert

w.j.kikkert@amc.uva.nl

1 Department of Cardiology, Academic Medical Center, University of Amsterdam, Meibergdreef 9, 1105 AZ Amsterdam, The Netherlands

2 Department of Clinical Chemistry, Academic Medical Center, University of Amsterdam, Amsterdam, The Netherlands patients treated with UFH boluses $\geq 130 \mathrm{IU} / \mathrm{kg}$ (OR 3.69; $95 \%$ CI 1.85-7.36; p for interaction $=0.009$ ). In conclusion, CKD is associated with severe persistent aPTT prolongation in STEMI patients undergoing PPCI, possibly due to impaired plasma protein binding and reduced UFH elimination. A lower heparin bolus dose might result in lower aPTTs and less bleeding complications in patients with CKD undergoing PPCI.

Keywords Unfractionated heparin - Acute myocardial infarction · Chronic kidney disease · Hemorrhage . Percutaneous coronary intervention

\section{Introduction}

Chronic kidney disease (CKD) is associated with increased mortality and major bleeding in patients undergoing primary percutaneous coronary intervention (PPCI) for STsegment elevation myocardial infarction (STEMI) [1, 2]. Therefore, considerable effort has been made to investigate the optimal adjunctive antithrombotic therapy to suppress both bleeding complications as well as recurrent ischemic outcomes in these patients. The European Society of Cardiology (ESC), American Heart Association (AHA) and American College of Cardiology (ACC) currently recommend the use of unfractionated heparin (UFH),enoxaparin or bivalirudin in STEMI patients undergoing PPCI [3, 4]. Of these 3 agents, UFH is currently the most commonly used anticoagulant for this indication [5, 6]. UFH was recently shown to be associated with lower rates of thrombotic events and similar bleeding events as compared to bivalirudin in a large scale all-comer randomized controlled trial reflecting contemporary practice (i.e. bail-out GP IIb/IIIa inhibitor use, radial access PCI and use of novel 
P2Y12 inhibitors) [7]. Therefore, UFH has gained renewed attention, and considering the low costs associated with its use, UFH will likely remain the most broadly applied anticoagulant in the routine clinical setting of PPCI for years to come. However, despite the extensive experience with UFH, the optimal UFH bolus dose during PPCI remains unknown, especially in patients with CKD.

The intensity of a drug's action is dependent on the free unbound concentration in the blood. Since plasma protein binding of anionic drugs is impaired in patients with renal failure, one can hypothesize that the unbound fraction of heparin (an anionic drug) after a bolus is increased in patients with renal failure, resulting in prolonged aPTTs. In addition, pharmacokinetic studies have shown that in low doses UFH is cleared by binding to endothelial cell receptors and by depolymerization by macrophages [8]. In high doses, clearance by endothelial cells and macrophages is saturated and additional clearance occurs by the kidneys $[9,10]$. Therefore, we hypothesized that the elimination of $\mathrm{UFH}$ in patients with CKD might be reduced and that administering repeated boluses to patients with CKD might result in prolonged UFH half-life and excess anticoagulation. Therefore the aim of the current analysis was to compare aPTT values within the first $12 \mathrm{~h}$ after PPCI in response to different UFH bolus doses for patients with and without CKD.

\section{Methods}

\section{Source population and procedures}

The data analyzed in this study were obtained from STEMI patients accepted for PPCI at the Academic Medical Center-University of Amsterdam between January 1, 2003, and July 31, 2008. The study complied with the Declaration of Helsinki, and the local ethics committee approved the study protocol. In general, patients qualified for PPCI if they had typical ischemic chest pain and at least $1 \mathrm{~mm}$ STsegment elevation in 2 or more contiguous leads, a new left bundle-branch block, or a true posterior myocardial infarction. Patients received a standard 300-600 mg loading dose clopidogrel. If a coronary stent was implanted, clopidogrel was prescribed for at least 1 month to patients with a bare metal stent and for 6-12 months to patients with a drug-eluting stent. Patients were routinely pretreated with $300 \mathrm{mg}$ aspirin and $5000 \mathrm{IU}$ unfractionated heparin, either in the ambulance during transfer to the catheterization laboratory, or in the referral hospital. An additional heparin bolus was administered at the catheterization laboratory if necessary, to maintain an aPTT approximately two times the upper limit of normal (ULN). This was followed by an infusion of $12 \mathrm{IU} / \mathrm{kg} / \mathrm{h}$, which was maintained up to 24-48 h after the procedure by our center's clinical protocol. APTT monitoring was required to be performed approximately every $6 \mathrm{~h}$. Adjustments to the infusion rate were subsequently made according to a dose nomogram which was derived from the standard ACC/AHA weight based dose-nomogram [11]. Glycoprotein IIb/IIIa inhibitors (GPIs) were used in a bail-out setting at the discretion of the operator. Patients treated with a GPI generally received a $0.25 \mathrm{mg} / \mathrm{kg}$ bolus abciximab intravenously followed by an $0.125 \mu \mathrm{g} / \mathrm{kg} / \mathrm{min}$ intravenous infusion for up to $12 \mathrm{~h}$ after the procedure, after which heparin therapy was reinitiated.

All laboratory assessments (including aPTT) were stored in the institutional laboratory database. Procedural and angiographic data were prospectively collected and entered by interventional cardiologists and specialized nurses in a dedicated database. Chart review for consecutive STEMI patients with available aPTT measurements was performed in the context of a study designed to investigate the relationship between aPTT and clinical outcome in STEMI patients treated with PPCI. A detailed description of the study protocol and study population has been previously published $[12,13]$.

Laboratory measurements (including aPTT, serum creatinine and hemoglobin) which were measured in referring hospitals were added to the study database. We obtained clinical history and detailed information on peri-procedural treatment from in-patients records in the PCI center and referring hospitals. We obtained follow-up of clinical outcome, including recurrent $\mathrm{MI}$, stroke, stent thrombosis, revasularization procedures and bleeding, by reviewing inand outpatients charts in the tertiary PCI center and referring hospitals between 2011 and 2012. For every patient, we systematically checked in-patients charts of every hospital admission for the occurrence of clinical events, including hemorrhagic events and their location. Follow-up of clinical events was censored at the actual date of chart review. Patients whose whereabouts could not be traced were considered lost to follow-up from the date of last known medical contact. Follow-up information regarding vital status was obtained from computerized, long-term mortality records from the National Death Index. If a patient could not be identified in these records (e.g. foreign patients), censoring was at the date of last contact. For the present analysis, patients were censored at the date of death or at hospital discharge, whichever came first.

\section{Study design}

Patients were eligible for inclusion in the analysis if: (1) they had typical ischemic chest pain and at least $1 \mathrm{~mm}$ STsegment elevation in 2 or more contiguous leads, a new left bundle-branch block, or a true posterior myocardial 
infarction; (2) an aPTT was recorded between arterial sheath insertion and $12 \mathrm{~h}$ thereafter and (3) a serum creatinine was recorded pre-procedurally or within $1 \mathrm{~h}$ of arterial puncture. We excluded patients who were pretreated with both UFH and low molecular weight heparin (LMWH).

\section{Measurements and definitions}

For each patient we used the first aPTT measured after arterial sheath insertion and categorized these aPTTs in the following time-intervals: from $0 \mathrm{~h}$ until $6 \mathrm{~h}$ (referred to as: ' 6 h'), from 6 h until $12 \mathrm{~h}$ (referred to as: ' $12 \mathrm{~h}$ '), and from $0 \mathrm{~h}$ until $12 \mathrm{~h}$ (referred to as: 'first $12 \mathrm{~h}$ '). All times were expressed relative to the moment of arterial sheath insertion at the start of PPCI. APTT ratios were stratified in the following groups: subtherapeutic (below 1.5 times control), therapeutic: between 1.5 and 2.0 times control; high: between 2.0 and 3.99 times control; and markedly high: $\geq 4$ times control. APTTs are presented in relation to the hospital and reagent specific upper limit of normal. If the electronic laboratory database indicated a value ' 0 ' for aPTT, this measurement was treated as not having been performed. In case a patient had no measurements within a given time interval, the value for that time interval was declared missing. The Cockcroft Gault formula was used to calculate creatinine clearance [14]. Baseline creatinine clearance was calculated from the serum creatinine measurement that was closest to the moment of arterial sheath insertion. CKD was defined as creatinine clearance $<60 \mathrm{ml} / \mathrm{min}$.

\section{Outcome definitions}

Primary outcome was aPTT within the first $6 \mathrm{~h}$ after PCI. Secondary outcomes included aPTT at different time intervals after PCI (specified above), the in hospital occurrence of Bleeding Academic Research Consortium defined bleeding complications, and the occurrence of major adverse cardiac events (MACE) during the initial hospitalization. MACE was defined as the non-hierarchical composite of cardiac mortality, recurrent $\mathrm{MI}$, stroke or target lesion revascularization (TLR). Recurrent MI and TLR were defined according to the Academic Research Consortium criteria [15]. Stroke was defined as an irreversible neurological deficit, as classified by a neurologist, on the basis of supporting information, including brain images and neurologic evaluation.

\section{Statistical analysis}

Normally distributed continuous variables are reported as the mean with standard deviation (SD) and compared with the Student $t$ test, skewed distributed variables are presented as the median with interquartile range (IQR) and compared with the Mann-Whitney $U$ test. Categorical variables are presented as proportions and compared with the $\chi^{2}$ test or Fisher's exact test.

To investigate the relationship between estimated creatinine clearance and aPTT ratio beyond four times control, we performed 3 sets of logistic regression analyses for each peri-procedural timeframe $(6,12 \mathrm{~h}$, first $12 \mathrm{~h})$ : (1) unadjusted; (2) adjusted for age, gender, bodymass, length/size, time to first aPTT measurement and heparin bolus dose, and (3) adjusted for relevant predictors of aPTT ratios beyond four times control. Relevant predictors for aPTT ratios beyond four times control were determined per timeframe, using stepwise backward elimination logistic regression analyses, including the following candidate covariables: gender, body mass, length, heparin bolus dose, time to first aPTT measurement, history of hypertension, diabetes, dyslipidemia, current smoking, stroke or TIA, peripheral artery disease, malignant disease, bleeding, recent surgery, previous MI, family history of CAD, anemia, leucocyte count, thrombocyte count, use of GP IIb/IIIa inhibitor, cardiogenic shock, and use of IABP. A covariate was included in the model if it influenced the model with a $\mathrm{p}<0.10$ by the likelihood ratio test and was removed if its significance level exceeded $\mathrm{p}=0.10$. To investigate if there was an interaction between UFH bolus dose and creatinine clearance $<60 \mathrm{ml} / \mathrm{min} / \mathrm{m}^{2}$ we included interaction terms between UFH bolus dose and creatinine clearance. The relationship between creatinine clearance and the in hospital occurrence of BARC type $\geq 3$ bleeding, and MACE was investigated by developing two sets of logistic regression models for each outcome: unadjusted and adjusted for relevant predictors of each outcome. Relevant predictors were determined using stepwise, backward elimination logistic regression analyses including all covariables with a significant unadjusted relationship with each outcome $(p<0.10)$. As a sensitivity analysis we performed an additional analysis including duration of heparin treatment and vitamin $\mathrm{K}$ antagonist treatment in addition to the previously identified predictors of bleeding in the multivariable model for BARC type $\geq 3$ bleeding. All tests were 2-sided and a p value below 0.05 was considered statistically significant. All statistical analyses were performed using Statistical Package for Social Sciences software (SPSS version 20.0, Chicago, Illinois).

\section{Results}

Between 1-1-2003 and 31-07-2008, a total of 3472 patients with acute myocardial infarction were admitted to our catheterization laboratory with an indication for PPCI. 1928 patients were excluded because these patients did not 
Table 1 Baseline, procedural and angiographic characteristics of the study patients

\begin{tabular}{|c|c|c|c|}
\hline \multirow[t]{2}{*}{ Characteristic } & \multicolumn{2}{|c|}{ Creatinine clearance (ml/min) } & \multirow[t]{2}{*}{$\mathrm{p}$ value } \\
\hline & $<60(\mathrm{n}=195)$ & $\geq 60(\mathrm{n}=876)$ & \\
\hline Male, n/N (\%) & $80 / 195(41.0)$ & $655 / 876(74.8)$ & $<0.001$ \\
\hline Age (years), mean $( \pm \mathrm{SD})$ & $76( \pm 8.6)$ & $59( \pm 11.8)$ & $<0.001$ \\
\hline Length (m), median (IQR) & $1.67(1.60-1.75)$ & $1.75(1.70-1.80)$ & $<0.001$ \\
\hline Body mass (kg), median (IQR) & $70(62-80)$ & $81(74-91)$ & $<0.001$ \\
\hline Body mass index, median (IQR) & $25.0(22.6-27.7)$ & $26.3(24.3-29.2)$ & $<0.001$ \\
\hline \multicolumn{4}{|l|}{ History of $\mathrm{n} / \mathrm{N}(\%)$} \\
\hline Diabetes & 35/195 (17.9) & $108 / 876(12.3)$ & 0.037 \\
\hline Hypertension & $84 / 195(43.1)$ & $304 / 876(34.7)$ & 0.028 \\
\hline Hypercholesterolemia & 32/195 (16.4) & $206 / 876(23.5)$ & 0.031 \\
\hline Current smoking & $44 / 195(22.6)$ & $443 / 876(50.6)$ & $<0.001$ \\
\hline Previous stroke or TIA & 20/195 10.3) & $48 / 876(5.5)$ & 0.013 \\
\hline Peripheral vascular disease & 30/195 (15.4) & $39 / 876(4.5)$ & $<0.001$ \\
\hline Pre-existent malignant disease & 32/195 (16.4) & $59 / 876(6.7)$ & $<0.001$ \\
\hline Recent surgery ( $<10$ days $)$ & $5 / 195(2.6)$ & 7/876 (0.8) & 0.050 \\
\hline Bleeding & $19 / 195(9.7)$ & $30 / 876(3.4)$ & $<0.001$ \\
\hline Previous MI & 27/195 (13.8) & $91 / 876(10.4)$ & 0.16 \\
\hline Previous PCI & $12 / 195(6.2)$ & $69 / 876(7.9)$ & 0.41 \\
\hline Previous CABG & $2 / 195(1.0)$ & $15 / 876(1.7)$ & 0.75 \\
\hline Family history CAD & $37 / 195(19.0)$ & $374 / 876(42.7)$ & $<0.001$ \\
\hline \multicolumn{4}{|l|}{ Laboratory values } \\
\hline White blood cell count $\geq 11 \times 10^{9} / \mathrm{l}, \mathrm{n} / \mathrm{N}(\%)$ & 94/191 (49.2) & $459 / 865(53.1)$ & 0.34 \\
\hline Anemia, $\mathrm{n} / \mathrm{N}(\%)^{\mathrm{a}}$ & 73/195 (37.4) & $102 / 875(11.7)$ & $<0.001$ \\
\hline Creatinine clearance, median $(\mathrm{IQR})^{\mathrm{b}}$ & $46.6(38.7-54.5)$ & $99.4(79.5-122)$ & $<0.001$ \\
\hline Thrombocyte count $\left(\times 10^{9} / 1\right), \mathrm{n} / \mathrm{N}(\%)$ & & & 0.21 \\
\hline$<150$ & $10 / 193(5.2)$ & $29 / 868(3.3)$ & \\
\hline $150-400$ & $173 / 193(89.6)$ & $810 / 868(93.3)$ & \\
\hline$>400$ & $10 / 193(5.2)$ & $29 / 868(3.3)$ & \\
\hline Total ischemic time (min),median (IQR) & $207(143-297)$ & $182(130-260)$ & 0.005 \\
\hline Cardiogenic shock, $\mathrm{n} / \mathrm{N}(\%)$ & 26/193 (13.5) & $60 / 873(6.9)$ & 0.002 \\
\hline IABP, $\mathrm{n} / \mathrm{N}(\%)^{\mathrm{c}}$ & $40 / 195(20.5)$ & 93/874 (10.6) & $<0.001$ \\
\hline Loading dose clopidogrel, $\mathrm{n} / \mathrm{N}(\%)$ & & & 0.001 \\
\hline $300 \mathrm{mg}$ & $116 / 194(59.8)$ & $513 / 865(59.3)$ & \\
\hline $600 \mathrm{mg}$ & 65/194 (33.5) & $333 / 865(38.5)$ & \\
\hline Other & $1 / 194(0.5)$ & $6 / 865(0.7)$ & \\
\hline Glycoprotein IIb/IIIa inhibitor, n/N (\%) & 23/195 (11.8) & $120 / 876(13.7)$ & 0.48 \\
\hline Pre-cathlab heparin bolus (IU/kg), median (IQR) & $67.6(55.6-80.6)$ & $58.8(50.0-67.6)$ & $<0.001$ \\
\hline Cathlab bolus dose (IU/kg), median (IQR) & $73.5(61.7-100)$ & $63.3(54.3-83.3)$ & $<0.001$ \\
\hline Total heparin bolus (IU/kg), median (IQR) & $134(106-182)$ & $125(100-149)$ & $<0.001$ \\
\hline Duration of heparin therapy $(\mathrm{h})$, median (IQR) & $40.5(21.0-50.0)$ & $45.0(20.5-50.5)$ & 0.66 \\
\hline Vitamin $\mathrm{K}$ antagonist at discharge, $\mathrm{n} / \mathrm{N}(\%)$ & $22 / 195(11.3)$ & $72 / 876(8.2)$ & 0.17 \\
\hline PCI access site, $\mathrm{n} / \mathrm{N}(\%)$ & & & 0.29 \\
\hline Femoral artery & $184 / 195(94.4)$ & $835 / 876(95.3)$ & \\
\hline Radial artery & $7 / 195(3.6)$ & $34 / 876(3.9)$ & \\
\hline Other or combinations & $4 / 195(2.1)$ & 7/876 (0.8) & \\
\hline Infarct related artery, $\mathrm{n} / \mathrm{N}(\%)$ & & & 0.87 \\
\hline RCA or LCx & $109 / 189(57.7)$ & $490 / 859(57.0)$ & \\
\hline LAD or LM & $80 / 189(42.3)$ & $369 / 859(43.0)$ & \\
\hline
\end{tabular}


Table 1 continued

\begin{tabular}{|c|c|c|c|}
\hline \multirow[t]{2}{*}{ Characteristic } & \multicolumn{2}{|c|}{ Creatinine clearance $(\mathrm{ml} / \mathrm{min})$} & \multirow[t]{2}{*}{$\mathrm{p}$ value } \\
\hline & $<60(\mathrm{n}=195)$ & $\geq 60(\mathrm{n}=876)$ & \\
\hline Pre-procedural TIMI flow in IRA, n/N (\%) & & & 0.41 \\
\hline $0 / 1$ & 132/177 (74.6) & $579 / 810(71.5)$ & \\
\hline $2 / 3$ & $45 / 177(25.4)$ & $231 / 810(28.5)$ & \\
\hline Post-procedural TIMI flow in IRA, n/N (\%) & & & $<0.001$ \\
\hline $0 / 1$ & 15/207 (8.1) & $14 / 840(1.7)$ & \\
\hline $2 / 3$ & 170/207 (91.9) & $826 / 840(98.3)$ & \\
\hline Mulitvessel disease, $\mathrm{n} / \mathrm{N}(\%)$ & 96/188 (51.1) & 273/854 (32.0) & $<0.001$ \\
\hline Chronic total occlusion, n/N (\%) & $39 / 188$ (20.7) & 93/854 (10.9) & $<0.001$ \\
\hline
\end{tabular}

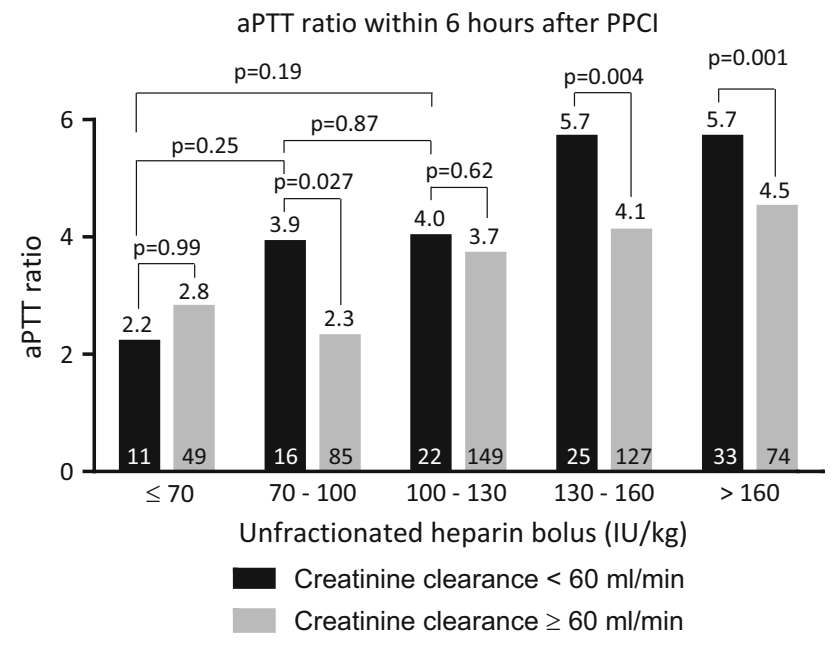

Fig. 1 The first aPTT ratio measurement between sheath insertion and $6 \mathrm{~h}$ thereafter according to the administered heparin bolus for patients with and without creatinine clearance $<60 \mathrm{ml} / \mathrm{min}$. For each heparin bolus dose, the aPTT ratio was outside the recommended range (between 1.5 and 2 times control). Above $70 \mathrm{IU} / \mathrm{kg} \mathrm{UFH,} \mathrm{aPTT}$ was higher in patients with creatinine clearance $<60 \mathrm{ml} / \mathrm{min}$. The difference in aPTT ratio seemed to increase with increasing bolus

have an aPTT measured between the start of PCI and $12 \mathrm{~h}$ thereafter or because they were not receiving UFH treatment at the time of the aPTT measurement. Of these 1544 patients baseline creatinine clearance was available in 1332 patients. Of these 1332 patients we had data on heparin bolus in 1185 patients. 114 patients were excluded from the analysis because they were pretreated with LMWH. Therefore, the study cohort consists of 1071 patients, of whom 195 patients $(18.2 \%)$ had an estimated creatinine clearance $<60 \mathrm{ml} / \mathrm{min}$. 16 patients had an estimated creatinine clearance $<30 \mathrm{ml} / \mathrm{min}$, of whom 2 had end stage renal disease (ESRD (defined as $\mathrm{CrCl}<15 \mathrm{ml} / \mathrm{min}$ )). Baseline, procedural and angiographic characteristics for patients in- and excluded in the analysis are given in supplementary Table 1. Patients included in the analysis were less likely to be male, and less likely to be treated with GP IIb/IIIa inhibitors. They more often presented in cardiogenic shock and were more often treated with intra-aortic balloon pump (IABP). One year mortality was $11.7 \%$ in patients included in the analysis, whereas mortality was $10.9 \%$ in patients excluded $(\mathrm{p}=0.52)$. The median total UFH bolus was $125 \mathrm{IU} / \mathrm{kg}$ (interquartile range (IQR): 100-154), consisting of a median pre-catheterisation laboratory bolus of $60 \mathrm{IU} / \mathrm{kg}$ (IQR 50-70) and an additional $66 \mathrm{IU} / \mathrm{kg}$ (IQR 56-83) given during the catheterisation procedure. In $87.1 \%$ of patients treated with $70-100 \mathrm{IU} / \mathrm{kg}$ UFH the aPTT measured within the first $6 \mathrm{~h}$ after PPCI was outside the recommended range (between 1.5 and 2.0 time ULN) and in as many as $66.3 \%$ of patients the aPTT was in excess of the recommended range. In $25.7 \%$ of patients aPTT was markedly prolonged ( $>4$ times ULN) after an $70-100 \mathrm{IU} / \mathrm{kg}$ UFH bolus dose. Baseline characteristics and treatment strategies by estimated creatinine clearance are presented in Table 1 . The aPTT ratio was 3.7 (interquartile range (IQR) 2.1-5.7) in the first $6 \mathrm{~h}$ after PPCI, 2.6 (IQR 1.7-4.2) between 6 and $12 \mathrm{~h}$ after PPCI and 3.1 (IQR 1.9-5.1) within the first $12 \mathrm{~h}$ after PPCI. In the first $6 \mathrm{~h}$ after PPCI, aPTT ratio was 5.1 for patients with CKD as compared to 3.4 for those without $(p<0.001)$. In the $6 \mathrm{~h}$ timeframe, aPTT measurements were obtained significantly later in patients with CKD $(2.4$ versus $2.0 \mathrm{~h}$, $\mathrm{p}=0.017)$. There was no statistically significant difference in time to first aPTT measurement in the $12 \mathrm{~h}$ time 
A Percentage of patients with aPTT ratio $\geq 4$ times ULN

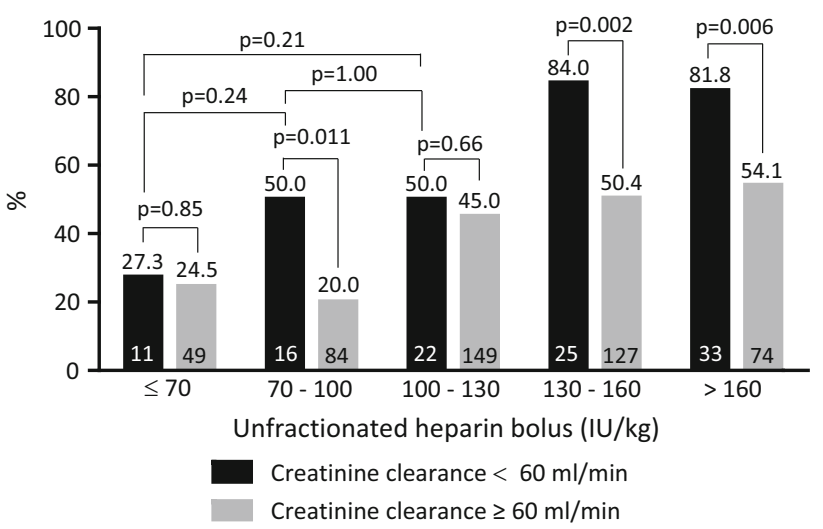

B Percentage of patients with subtherapeutic aPTT ratios $(<1.5$ times ULN)

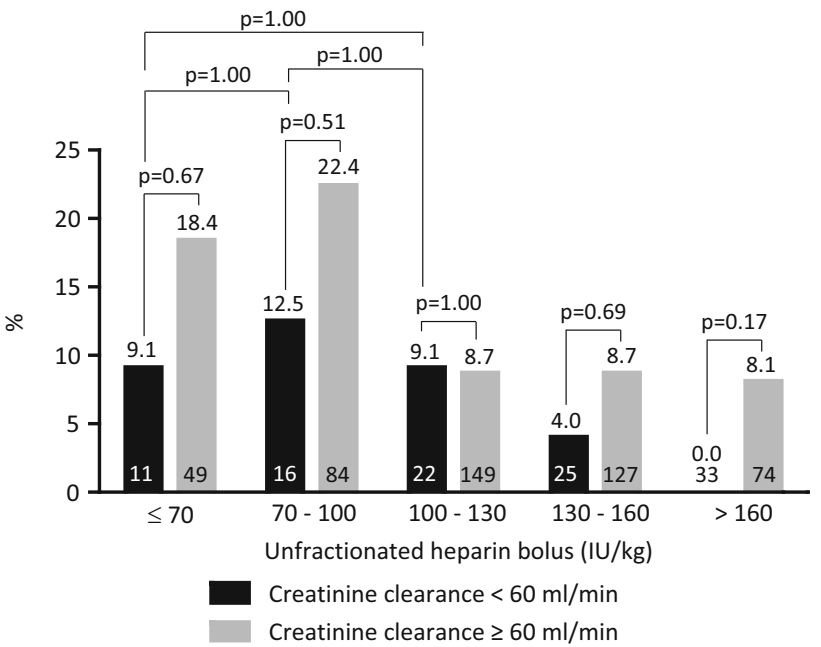

Fig. 2 a Percentage of patients with a mean aPTT ratio beyond four times control (measured the first $6 \mathrm{~h}$ after start of PPCI), as a function of unfractionated heparin bolus dose and creatinine clearance. For each heparin bolus dose, the percentage of patients with a mean aPTT ratio beyond four times control was higher for patients with CKD. The proportion of patients with markedly high aPTTs increased as the heparin bolus increased. The increase in risk of markedly high aPTTs with increasing UFH bolus was greater in patients with CKD, as compare to those without CKD. There was no statistically significant difference in markedly high aPTTs between the patients with CKD treated with a $\leq 70,70-100$, or $100-130 \mathrm{IU} / \mathrm{kg}$ UFH bolus dose ( $\mathrm{p} \geq 0.54$ ). The black and white numbers in the bars represent the number of patients in the respective patient group. b Percentage of patients with a mean aPTT ratio below 1.5 times control (measured within the first $6 \mathrm{~h}$ after start of PPCI), as a function of unfractionated heparin bolus dose and creatinine clearance. The proportion of patients with subtherapeutic aPTTs decreased as the heparin bolus decreased. Patients with CKD were less likely to have subtherapeutic aPTTs when boluses in excess of $70 \mathrm{IU} / \mathrm{kg}$ were used, although none of the comparisons were statistically significant. ULN indicates upper limit of normal

frame and first $12 \mathrm{~h}$ timeframe $(8.4$ and $6.6 \mathrm{~h}$ in patients with CKD as compared to 8.3 and $6.5 \mathrm{~h}$ in patients without $\mathrm{CKD} ; \mathrm{p}=0.78$ and $\mathrm{p}=0.25$ respectively).

\section{Renal function and anticoagulation with unfractionated heparin}

Figure 1 displays the aPTT ratio the first 6 after PPCI for patients with and without CKD according to different categories of UFH bolus. APTT ratios increased with increasing heparin bolus. Above $70 \mathrm{IU} / \mathrm{kg}$, aPTT ratios were higher for patients with CKD and the difference in aPTT ratios between patients with and without CKD seemed to increase with increasing heparin bolus, particularly with heparin boluses in excess of $130 \mathrm{IU} / \mathrm{kg}$. When the currently recommended UFH bolus was used (between 70 and $100 \mathrm{IU} / \mathrm{kg}$ ), aPTT ratio was significantly higher in patients with CKD. Supplementary Figs. 1 and 2 display aPTT ratios measured between 6 and $12 \mathrm{~h}$ after PPCI and the first $12 \mathrm{~h}$ after PPCI respectively according to different categories of UFH bolus for patients with and without CKD. Results were similar to aPTT ratios within the first $6 \mathrm{~h}$ after PPCI, although the differences between patients with and without CKD were even more prominent. Figure 2a displays the proportion of patients with markedly high aPTTs ( $\geq 4$ times ULN) for patients with and without CKD according to heparin bolus. The proportion of patients with markedly high aPTT ratios increased with increasing heparin bolus. For every heparin bolus the proportion of patients with excess anticoagulation was higher in patients with CKD. When the recommended bolus was used, the proportion of patients with excess anticoagulation among those with CKD was as high as $50.0 \%$. Beyond $130 \mathrm{IU} / \mathrm{kg}$ the difference between patients with and without CKD who had a markedly high aPTT significantly increased. There was no statistically significant difference in markedly high aPTTs between the patients with CKD treated with $\leq 70 \mathrm{IU} / \mathrm{kg}, \quad 70-100$ or $100-130 \mathrm{IU} / \mathrm{kg}$ bolus dose $(\mathrm{p} \geq 0.21)$. The results were consistent when the relationship between CKD, heparin bolus and aPTT ratio were investigated for the other timeframes (between 6 and $12 \mathrm{~h}$ after PPCI and the first $12 \mathrm{~h}$ after PPCI; supplementary Figs. 3 and 4 respectively). Figure $2 \mathrm{~b}$ displays the proportion of patients with subtherapeutic aPTT ratios for patients with and without CKD according to heparin bolus. The proportion of patients with subtherapeutic aPTT ratios decreased as the heparin bolus increased. The proportion of patients with subtherapeutic aPTT ratios tended to be smaller in patients with CKD, as compared to those without CKD. However the differences did not reach statistical significance. Figure 3 shows the distribution of patients with subtherapeutic, therapeutic, high and markedly high aPTT ratios recorded the first $6 \mathrm{~h}$ after start of the PPCI for patients with and without CKD according to UFH bolus. Supplementary Figures 5 and 6 show these data for the mean aPTT ratios recorded between 6 and $12 \mathrm{~h}$ after PPCI and for the first $12 \mathrm{~h}$ after PPCI respectively. 


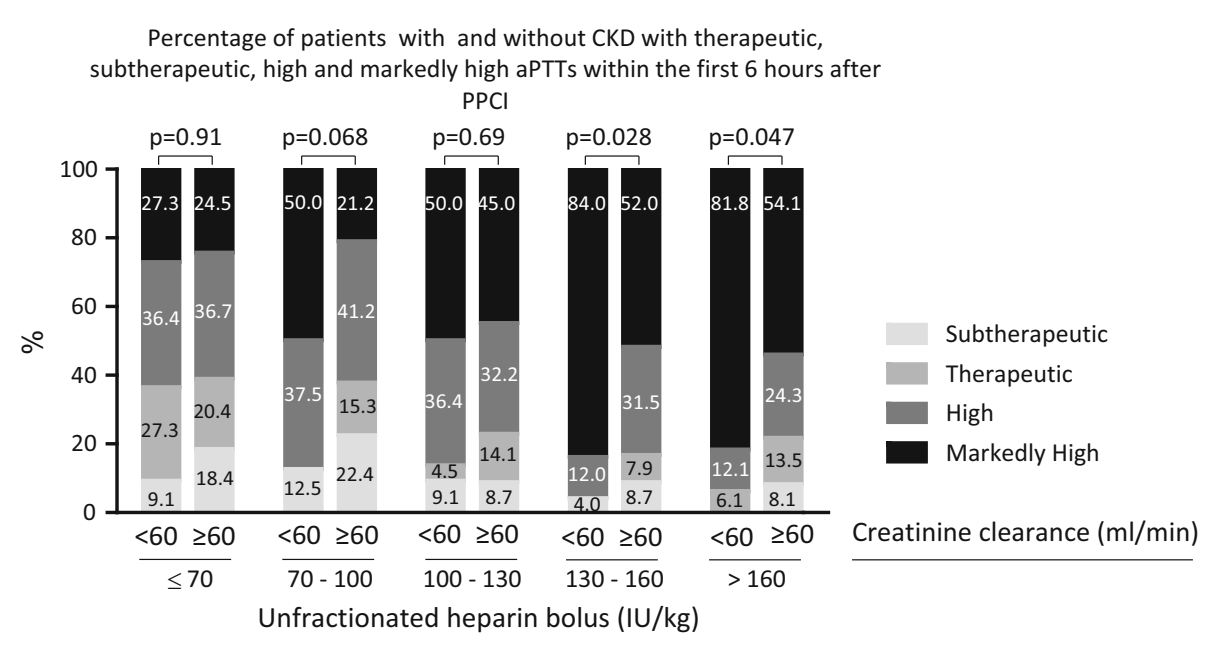

Fig. 3 Percentage of patients with therapeutic, subtherapeutic, high and markedly aPTT ratios (measured within $6 \mathrm{~h}$ after PPCI), as a function of unfractionated heparin bolus dose and creatinine clearance. Irrespective of the bolus dose heparin, the proportion of patients with an aPTT ratio within the recommended range (1.5-2.0 times control) was low and most of the patients had an aPTT ratio in excess of the recommended range. With increasing heparin bolus dose, the proportion of patients with high and markedly high aPTT ratios

Table 2 provides unadjusted and adjusted odds ratios (ORs) for aPTT beyond 4 times control according to the presence of CKD. CKD was an independent predictor of aPTT beyond four times control. This risk was independent of other components of the Cockcroft-Gault equation of estimated creatinine clearance. The risk of markedly high aPTTs in patients with CKD was mainly driven by the increased risk of markedly high aPTTs when a heparin bolus in excess of $130 \mathrm{IU} / \mathrm{kg}$ was administered. To investigate if the increase in proportion of patients with markedly high aPTTs with increasing heparin bolus dose was significantly greater for patients with CKD, as compared to those without, we included an interaction term between heparin bolus and creatinine clearance in the multivariable logistic regression analyses. There was a significant interaction between UFH bolus dose (above or below $130 \mathrm{IU} / \mathrm{kg}$ ) and CKD, indicating that beyond $130 \mathrm{IU} / \mathrm{kg}$, there was a stronger risk of markedly high aPTTs (measured within the first $6 \mathrm{~h}$ and the first $12 \mathrm{~h}$ after PPCI) in patients with CKD, as compared to those without.

Supplementary Table 2 provides unadjusted and adjusted ORs for aPTT beyond four times control according to estimated creatinine clearance as a continuous variable. Again, creatinine clearance was an independent predictor of markedly high aPTTs, both between 0 and $6 \mathrm{~h}$ after PPCI and 6-12 h after PPCI.

\section{CKD and clinical outcome}

Creatinine clearance $<60 \mathrm{ml} / \mathrm{min}$ was independently associated with in hospital BARC type $\geq 3$ bleeding and MACE increased, whereas the proportion of patients with subtherapeutic and therapeutic aPTT ratios decreased. For patients with CKD, the proportion of patients with therapeutic aPTT ratios was numerically highest when a dose below $70 \mathrm{IU} / \mathrm{kg}$ was used, although this proportion was not statistically significant different from the proportion of patients with therapeutic aPTT ratios when a 70-100 or $100-130 \mathrm{IU} / \mathrm{kg}$ was used $(\mathrm{p} \geq 0.056)$

(Table 2). Other predictors of in-hospital BARC type $\geq 3$ bleeding and MACE are presented in Tables 2 and 3 of the online appendix. In a sensitivity analysis additionally adjusting for duration of heparin therapy and vitamin $\mathrm{K}$ antagonist treatment, CKD remained independently associated with in hospital BARC type $\geq 3$ bleeding.

\section{Discussion}

The main findings of this study can be summarized as follows. After repeated UFH boluses a more persistent aPTT prolongation occurs in patients with CKD as compared to those without CKD. After multivariable adjustments, CKD was an independent predictor of aPTT prolongation. Patients with CKD are particularly at high risk of markedly high aPTTs and bleeding when bolus doses in excess of $130 \mathrm{IU} / \mathrm{kg}$ are used.

Several mechanisms may be responsible for the persistent aPTT prolongation in patients with CKD. First, the plasma protein binding of UFH might be reduced in patients with renal failure, thus increasing the free concentration in plasma. The strength of a drug's action is related to the drug's peak concentration in plasma. The peak concentration of a drug after an initial bolus is dependent on the bolus dose and the volume of distribution, which in turn is strongly dependent on plasma protein binding. Plasma protein bound drugs are largely inactive. Therefore, reduced plasma protein binding may result in more free drug available at the site of action. The binding 


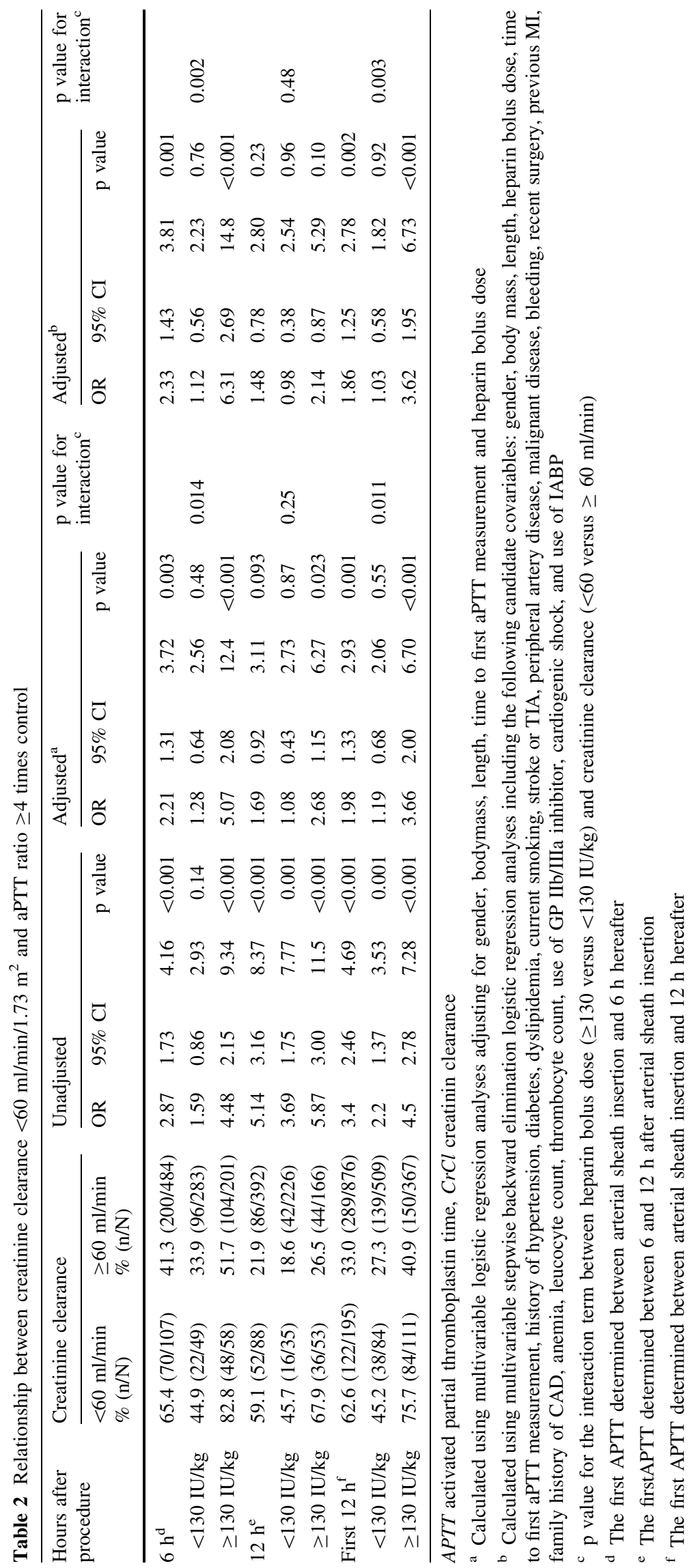


Table 3 Relationship between creatinine clearance and in hospital clinical outcome

\begin{tabular}{|c|c|c|c|c|c|c|c|c|c|c|}
\hline \multirow[t]{2}{*}{ Outcome } & \multirow[t]{2}{*}{ Creatinine clearance } & \multirow[t]{2}{*}{ No. $(\%)$ of patients } & \multicolumn{4}{|c|}{ Unadjusted } & \multicolumn{2}{|c|}{ Adjusted } & & \multirow[b]{2}{*}{$\mathrm{p}$ value } \\
\hline & & & OR & $95 \% \mathrm{CI}$ & & $\mathrm{p}$ value & OR & $95 \% \mathrm{CI}$ & & \\
\hline \multicolumn{11}{|c|}{ In hospital BARC type $\geq 3$ bleeding } \\
\hline & $<60(\mathrm{ml} / \mathrm{min})$ & $63 / 195(32.3)$ & 4.33 & 2.98 & 6.29 & $<0.001$ & $2.78^{\mathrm{a}}$ & 1.81 & 4.27 & $<0.001$ \\
\hline & $\geq 60(\mathrm{ml} / \mathrm{min})$ & $87 / 876(9.9)$ & 1 & - & - & - & 1 & - & - & - \\
\hline \multicolumn{11}{|c|}{ In hospital MACE } \\
\hline & $<60(\mathrm{ml} / \mathrm{min})$ & $51 / 195(26.2)$ & 4.02 & 2.69 & 6.00 & $<0.001$ & $2.52^{\mathrm{b}}$ & 1.56 & 4.08 & $<0.001$ \\
\hline & $\geq 60(\mathrm{ml} / \mathrm{min})$ & $71 / 876(8.1)$ & 1 & - & - & - & 1 & - & - & - \\
\hline
\end{tabular}

$O R$ odds ratio, $C I$ confidence interval, BARC bleeding academic research consortium, MACE major adverse cardiac event

a Calculated using logistic regression analysis adjusting for the use of GP IIb/IIIa inhibitor, intra-aortic balloon counterpulsation, gender, body mass index, and multivessel disease (with or without chronic total occlusion). The results of the multivariable model are given in online supplementary Table 3

${ }^{\mathrm{b}}$ Calculated using logistic regression analysis adjusting for family history of coronary artery disease, GP IIb/IIIa inhibitor, intra-aortic balloon counterpulsation, cardiogenic shock, anemia, white blood cell count, thrombocyte count, infarct related artery and multivessel disease (with or without chronic total occlusion). The results of the multivariable model are given in online supplementary Table 4

of anion drugs to plasma proteins in patients with renal failure is reduced [16]. Thus, the free fraction of unfractionated heparin, an anion drug, might be enhanced in patients with renal failure, explaining the aPTT prolongation in patients with CKD found in the current study. Second, in low and therapeutic doses, heparin is cleared by the reticuloendothelial system [8]. Renal failure is associated with abnormal function of the reticuloendothelial system and impaired function of macrophages [17-19]. Therefore, we hypothesize that clearance of heparin by the reticuloendothelial system might be reduced in patients with CKD. Third, in high doses UFH is cleared by the kidneys $[9,10]$. Therefore, accumulation of heparin and its anticoagulant properties may occur in patients with decreased renal function. Fourth, it is possible that a higher prevalence of other, unmeasured causes of aPTT prolongation may have contributed to aPTT prolongation in patients with CKD, such as vitamin K deficiency [20], coagulation factor deficiencies [21], acquired clotting factor inhibitors [22], disseminated intravascular coagulation [23], and massive blood transfusion leading to a dilutional coagulopathy [24]. These disorders however are extremely rare, therefore it is unlikely that imbalances in the prevalence of these disorders among patients with and without CKD are the causative factors for aPTT prolongation.

Consistent with previous studies, CKD was associated with an increased risk of bleeding after PPCI after adjustment for confounders [1]. Possible explanations for the increased bleeding risk among patients with $\mathrm{CKD}$, include functional abnormalities in platelets, abnormal plateletvessel wall interaction and adverse effects of anemia [25]. The present analysis suggests an additional, modifiable mechanism. We showed that CKD was associated with high aPTT values, which are known to be associated with an increased risk of severe bleeding $[12,26]$. It is possible that this is the result of impaired clearance of UFH secondary to CKD.

\section{Limitations}

Several limitation to the present analysis deserve mentioning. First, in a significant proportion of patients the administered bolus dose heparin exceeded the currently recommended 70-100 IU/kg bolus dose [3, 4]. We used a fixed bolus dose UFH, corresponding to a wide variety of weight-adjusted doses, and this allowed us to investigate the effect of a broad variety of bolus doses on aPTT in patients with and without CKD. Moreover, the evidence in favour of the currently recommended bolus dose is scarce. In fact, in the present analysis, in as little as $16.8 \%$ of patients in whom the recommended bolus dose was used the aPTT was in the recommended aPTT range, and in as many as $62 \%$ of patients the aPTT was in excess of the recommended range. Second, the ACC/AHA currently recommend using $\mathrm{ACT}$ to monitor heparin treatment during PPCI [4]. However, it has been shown that aPTT is more closely related to heparin concentration in blood compared to ACT [27, 28]. Thus, aPTT is the appropriate measure to investigate if accumulation of heparin occurs in STEMI patients with CKD. Finally, as a result of the relatively small number of patients included in the analysis, it is possible that we could not detect significant differences in therapeutic, subtherapeutic high and markedly high aPTT ratios for patient with and without CKD, when different UFH bolus doses below $130 \mathrm{IU} / \mathrm{kg}$ were used. 


\section{Conclusion}

In STEMI patients with CKD undergoing PPCI, the risk of severe more persistent aPTT prolongation strongly increases with increasing heparin bolus, particularly beyond $130 \mathrm{IU} / \mathrm{kg}$. Therefore, to reduce the risk of bleeding in these vulnerable patients, a UFH bolus dose below $130 \mathrm{IU} / \mathrm{kg}$ should be used. Adequately powered randomised controlled trials investigating the optimal UFH bolus dose in STEMI patients undergoing PPCI are needed.

Acknowledgments The authors greatly acknowledge the staff of the departments of cardiology of the following hospitals for their assistance during data collection (alphabetical order): BovenIJ Ziekenhuis, Bronovo, Diakonessenhuis Utrecht, Flevoziekenhuis, Gelre Ziekenhuizen, Gemini Ziekenhuis, HagaZiekenhuis, Kennemer Gasthuis, MC Zuiderzee, Meander Medisch Centrum, Medisch Centrum Alkmaar, Medisch Centrum Haaglanden, Onze Lieve Vrouwe Gasthuis, Rode Kruis Ziekenhuis Beverwijk, Sint Lucas Andreas Ziekenhuis, Slotervaartziekenhuis, Spaarne Ziekenhuis, St. Antonius Ziekenhuis, Tergooiziekenhuizen, Vrije Universiteit Medisch Centrum, Westfriesgasthuis, Ziekenhuis Amstelland, Zuwe Hofpoort Ziekenhuis.

Funding This study was funded by The Nuts OHRA Foundation, the Netherlands [SNO-T-0702-61].

\section{Compliance with ethical standards}

Conflict of interest The authors declare that they have no conflict of interest.

Open Access This article is distributed under the terms of the Creative Commons Attribution 4.0 International License (http://crea tivecommons.org/licenses/by/4.0/), which permits unrestricted use, distribution, and reproduction in any medium, provided you give appropriate credit to the original author(s) and the source, provide a link to the Creative Commons license, and indicate if changes were made.

\section{References}

1. Saltzman AJ, Stone GW, Claessen BE, Narula A, Leon-Reyes S, Weisz G, Brodie B, Witzenbichler B, Guagliumi G, Kornowski R, Dudek D, Metzger DC, Lansky AJ, Nikolsky E, Dangas GD, Mehran R (2011) Long-term impact of chronic kidney disease in patients with ST-segment elevation myocardial infarction treated with primary percutaneous coronary intervention: the HORIZONS-AMI (Harmonizing Outcomes With Revascularization and Stents in Acute Myocardial Infarction) trial. JACC Cardiovasc Interv 4(9):1011-1019. doi:10.1016/j.jcin.2011.06.012

2. Vasu S, Gruberg L, Brown DL (2007) The impact of advanced chronic kidney disease on in-hospital mortality following percutaneous coronary intervention for acute myocardial infarction. Catheter Cardiovasc Interv 70(5):701-705. doi:10.1002/ccd. 21223

3. Steg PG, James SK, Atar D, Badano LP, Lundqvist CB, Borger MA, Di Mario C, Dickstein K, Ducrocq G, Fernandez-Aviles F, Gershlick AH, Giannuzzi P, Halvorsen S, Huber K, Juni P, Kastrati A, Knuuti J, Lenzen MJ, Mahaffey KW, Valgimigli M, van't Hof A, Widimsky P, Zahger D, Guidelines ECFP, Bax JJ, Baumgartner H, Ceconi C, Dean V, Deaton C, Fagard R, FunckBrentano C, Hasdai D, Hoes A, Kirchhof P, Kolh P, McDonagh T, Moulin C, Popescu BA, Reiner Ž, Sechtem U, Sirnes PA, Tendera M, Torbicki A, Vahanian A, Windecker S, Reviewers D, Astin F, Åström-Olsson K, Budaj A, Clemmensen P, Collet J-P, Fox KA, Fuat A, Gustiene O, Hamm CW, Kala P, Lancellotti P, Maggioni AP, Merkely B, Neumann F-J, Piepoli MF, Van de Werf F, Verheugt F, Wallentin L (2012) ESC guidelines for the management of acute myocardial infarction in patients presenting with ST-segment elevation: the task force on the management of ST-segment elevation acute myocardial infarction of the European society of cardiology (ESC). Eur Heart J 33(20):2569-2619. doi:10.1093/eurheartj/ehs215

4. O’Gara PT, Kushner FG, Ascheim DD, Casey DE, Chung MK, de Lemos JA, Ettinger SM, Fang JC, Fesmire FM, Franklin BA, Granger CB, Krumholz HM, Linderbaum JA, Morrow DA, Newby LK, Ornato JP, Ou N, Radford MJ, Tamis-Holland JE, Tommaso CL, Tracy CM, Woo YJ, Zhao DX (2012) 2013 ACCF/ AHA guideline for the management of st-elevation myocardial infarction: a report of the American College of Cardiology Foundation/American Heart Association task force on practice guidelines. Circulation. doi:10.1161/CIR.0b013e3182742cf6

5. Kikkert WJ, Piek JJ, de Winter RJ, Peters RJ, Henriques JP (2010) Guideline adherence for antithrombotic therapy in acute coronary syndrome: an overview in Dutch hospitals. Neth Heart J 18(6):291-299

6. Kadakia MB, Desai NR, Alexander KP, Chen AY, Foody JM, Cannon CP, Wiviott SD, Scirica BM (2010) Use of anticoagulant agents and risk of bleeding among patients admitted with myocardial infarction: a report from the NCDR ACTION registry-GWTG (national cardiovascular data registry acute coronary treatment and intervention outcomes network registry-get with the guidelines). JACC 3(11):1166-1177. doi:10.1016/j.jcin. 2010.08.015

7. Shahzad A, Kemp I, Mars C, Wilson K, Roome C, Cooper R, Andron M, Appleby C, Fisher M, Khand A, Kunadian B, Mills JD, Morris JL, Morrison WL, Munir S, Palmer ND, Perry RA, Ramsdale DR, Velavan P, Stables RH (2014) Unfractionated heparin versus bivalirudin in primary percutaneous coronary intervention (HEAT-PPCI): an open-label, single centre, randomised controlled trial. Lancet. doi:10.1016/s0140-6736(14)60924-7

8. Dawes J, Prowse CV, Pepper DS (1986) Absorption of heparin, LMW heparin and SP54 after subcutaneous injection, assessed by competitive binding assay. Thromb Res 44(5):683-693

9. Caranobe C, Barret A, Gabaig AM, Dupouy D, Sie P, Boneu B (1985) Disappearance of circulating anti-Xa activity after intravenous injection of standard heparin and of a low molecular weight heparin (CY 216) in normal and nephrectomized rabbits. Thromb Res 40(1):129-133

10. Boneu B, Caranobe C, Cadroy Y, Dol F, Gabaig AM, Dupouy D, Sie $\mathrm{P}$ (1988) Pharmacokinetic studies of standard unfractionated heparin, and low molecular weight heparins in the rabbit. Semin Thromb Hemost 14(1):18-27. doi:10.1055/s-2007-1002751

11. Antman EM, Hand M, Armstrong PW, Bates ER, Green LA, Halasyamani LK, Hochman JS, Krumholz HM, Lamas GA, Mullany CJ, Pearle DL, Sloan MA, Smith SC, Members WC, Anbe DT, Kushner FG, Ornato JP, Jacobs AK, Adams CD, Anderson JL, Buller CE, Creager MA, Ettinger SM, Halperin JL, Hunt SA, Lytle BW, Nishimura R, Page RL, Riegel B, Tarkington LG, Yancy CW (2008) 2007 focused update of the ACC/ AHA 2004 guidelines for the management of patients with STelevation myocardial infarction. Circulation 117(2):296-329. doi:10.1161/circulationaha.107.188209

12. Kikkert WJ, van Nes SH, Lieve KV, Dangas GD, van Straalen J, Vis M, Baan J Jr, Koch KT, de Winter RJ, Piek JJ, Tijssen JG, 
Henriques JP (2013) Prognostic value of post-procedural aPTT in patients with ST-elevation myocardial infarction treated with primary PCI. Thromb Haemost 109(5):961-970. doi:10.1160/ th12-10-0726

13. Kikkert WJ, van Geloven N, van der Laan MH, Vis MM, Baan J Jr, Koch KT, Peters RJ, de Winter RJ, Piek JJ, Tijssen JG, Henriques JP (2014) The prognostic value of bleeding academic research consortium (BARC)-defined bleeding complications in ST-segment elevation myocardial infarction: a comparison with the TIMI (thrombolysis in myocardial infarction), GUSTO (global utilization of streptokinase and tissue plasminogen activator for occluded coronary arteries), and ISTH (international society on thrombosis and haemostasis) bleeding classifications. J Am Coll Cardiol 63(18):1866-1875. doi:10.1016/j.jacc.2014.01.069

14. Cockcroft DW, Gault MH (1976) Prediction of creatinine clearance from serum creatinine. Nephron 16(1):31-41

15. Cutlip DE, Windecker S, Mehran R, Boam A, Cohen DJ, van Es GA, Steg PG, Morel MA, Mauri L, Vranckx P, McFadden E, Lansky A, Hamon M, Krucoff MW, Serruys PW (2007) Clinical end points in coronary stent trials: a case for standardized definitions. Circulation 115(17):2344-2351. doi:10.1161/circulatio naha.106.685313

16. Vanholder R, Van Landschoot N, De Smet R, Schoots A, Ringoir $S$ (1988) Drug protein binding in chronic renal failure: evaluation of nine drugs. Kidney Int 33(5):996-1004

17. Sousa VRA, Sousa AA, Petroianu A, Simal CJR, Barbosa AJA (2001) Influence of acute renal failure on the mononuclear phagocytic system. Braz J Med Biol Res 34:1169-1174

18. Ruiz P, Gomez F, Schreiber AD (1990) Impaired function of macrophage $\mathrm{Fc} \gamma$ receptors in end-stage renal disease. N Engl J Med 322(11):717-722. doi:10.1056/NEJM199003153221102

19. Mahadoo J, Heibert L, Jaques LB (1978) Vascular sequestration of heparin. Thromb Res 12(1):79-90

20. Holden RM, Morton AR, Garland JS, Pavlov A, Day AG, Booth SL (2010) Vitamins K and D status in stages 3-5 chronic kidney disease. Clin J Am Soc Nephrol 5(4):590-597. doi:10.2215/cjn. 06420909

21. Turi DC, Peerschke EI (1986) Sensitivity of three activated partial thromboplastin time reagents to coagulation factor deficiencies. Am J Clin Pathol 85(1):43-49

22. Kamal AH, Tefferi A, Pruthi RK (2007) How to interpret and pursue an abnormal prothrombin time, activated partial thromboplastin time, and bleeding time in adults. Mayo Clin Proc 82(7):864-873. doi:10.4065/82.7.864

23. Fisher VR, Scott MK, Tremblay CA, Beaulieu GP, Ward DC, Byrne KM (2013) Disseminated intravascular coagulation: laboratory support for management and treatment. Lab Med 44(Supplement):e10-e14. doi:10.1309/lmtcavnhbugwtp7k

24. Yuan S, Ferrell C, Chandler WL (2007) Comparing the prothrombin time INR versus the APTT to evaluate the coagulopathy of acute trauma. Thromb Res 120(1):29-37. doi:10.1016/j. thromres.2006.07.002

25. Boccardo P, Remuzzi G, Galbusera M (2004) Platelet dysfunction in renal failure. Semin Thromb Hemost 30(5):579-589. doi:10.1055/s-2004-835678

26. Granger CB, Hirsch J, Califf RM, Col J, White HD, Betriu A, Woodlief LH, Lee KL, Bovill EG, Simes RJ, Topol EJ (1996) Activated partial thromboplastin time and outcome after thrombolytic therapy for acute myocardial infarction: results from the GUSTO-I trial. Circulation 93(5):870-878

27. Koerber JM, Smythe MA, Begle RL, Mattson JC, Kershaw BP, Westley SJ (1999) Correlation of activated clotting time and activated partial thromboplastin time to plasma heparin concentration. Pharmacotherapy 19(8):922-931. doi:10.1592/phco.19. 11.922.31573

28. Smythe M, Koerber J, Nowak S, Mattson J, Begle R, Westley S, Balasubramaniam M (2002) Correlation between activated clotting time and activated partial thromboplastin times. Ann Pharmacother 36(1):7-11. doi:10.1345/aph.1A141 